\title{
2值データにおける顕示変数の効率的な選択手法 Efficient Variable Selection Method for Exposure Variables on Binary Data
}

\author{
大野 学 \\ 垂水 共之
}

岡山大学大学院自然科学研究科資源管理科学専攻

Graduate School of Natural Science and Technology, Okayama University, 3-1-1 Tsushima-Naka, Okayama 700-8530, Japan

ohno@ems. okayama-u.ac.jp

岡山大学アドミッションセンター

Admission Center, Okayama University, 3-1-1 Tsushima-Naka, Okayama 700-8530, Japan

tarumi@ems.okayama-u.ac.jp

keywords: AIC, apriori algorithm, anti-monotone, chi-squared test

\section{Summary}

In this paper, we propose a new variable selection method for "robust" exposure variables. We define "robust" as property that the same variable can select among original data and perturbed data. There are few studies of effective for the selection method. The problem that selects exposure variables is almost the same as a problem that extracts correlation rules without robustness. [Brin 97] is suggested that correlation rules are possible to extract efficiently using chi-squared statistic of contingency table having monotone property on binary data. But the chi-squared value does not have monotone property, so it's is easy to judge the method to be not independent with an increase in the dimension though the variable set is completely independent, and the method is not usable in variable selection for robust exposure variables. We assume anti-monotone property for independent variables to select robust independent variables and use the apriori algorithm for it. The apriori algorithm is one of the algorithms which find association rules from the market basket data. The algorithm use anti-monotone property on the support which is defined by association rules. But independent property does not completely have anti-monotone property on the AIC of independent probability model, but the tendency to have anti-monotone property is strong. Therefore, selected variables with anti-monotone property on the AIC have robustness. Our method judges whether a certain variable is exposure variable for the independent variable using previous comparison of the AIC. Our numerical experiments show that our method can select robust exposure variables efficiently and precisely.

1.は じめに

近年，商品選好のWeb アンケート調査 , 流通業のPOS データといった購買履歴データ等の質的情報を多く含む データが , 大量に安価に入手・蓄積することが可能になっ た．弚のような質的データは，特にマーケティング分野 に多く存在し，データの分析結果に基づいて企業の商品 開発，ターゲットマーケティングへの意思決定がなされ る場合が多い，一般に分析者は, 調査項目や商品の購買 を表す変数同士の関連性に興味がある場合が多い，逆に， 関連性がないという情報は，あまり有益でない，本稿で は，関連性がないことと独立であることを同じとみなし て扱う.

研究者は，いったん独立であると判断した変数をあら ためて取り上げ, 新たな要因に照らし合わせて再分析し ようとは，あまり思いつかないと [松田 88] は指摘して おり，これは研究者だけでなく，一般のデータ分析者に も同じことがいえ.また，分析コストの問題で，兴の
ような新たな変数 (要因) の存在を仮定せずに分析する場 合もある.よって, 光の変数の存在の発見は, 重要な問 題であり，乥れらを効率よく発見 (選択) し分析者に知ら せることは有益であると考える．

いったん独立であると判断した変数に, 新たな変数を照

表 1 顕示変数の例

\begin{tabular}{c|c|cc|c} 
性別 & 商品 $\mathrm{A}$ & \multicolumn{2}{|c|}{ 商品 $\mathrm{B}$} & \multirow{2}{*}{ オッズ比 } \\
\cline { 3 - 4 } & & 購入 & 非購入 & \\
\hline 女 & 購入 & 75 & 150 & 0.25 \\
& 非購入 & 600 & 300 & \\
男 & 購入 & 275 & 50 & 5.5 \\
& 非購入 & 100 & 100 &
\end{tabular}

らし合わせて再分析すると，光の関係が成り立たなくな るとき，新たな変数のことを一般に顕示変数 (exposure variable) を呼ぶ .ここで, 顕示変数の例を表 1 の分割 表を使って示す .この分割表は, 性別ごとの商品 $\mathrm{A}$ と商 
品 B の同時購買の人数を表すものである . 性別のカテゴ リーを潰した (collapse) 商品 $\mathrm{A} \times$ 商品 $B$ の分割表のオッ ズ比は $\frac{(350 / 200)}{(700 / 400)}=1$ で独立がいえ光うであるが，表 1 の ように性別を考慮した 3 元分割表では, 关の関係が成り 立たない.よって, 性別か顕示変数になる。

顕示変数についてより正確に定義するために, [松田 88] の定義に従い，確率モデルを使って定義する．

変数 $X_{i}(i=1, \cdots, p)$ は, 0,1 の值をとる $\cdot p$ 次の同時 確率 $p\left(x_{1}, \cdots, x_{p}\right)$ は

$$
\sum_{x_{1}=0}^{1} \cdots \sum_{x_{p}=0}^{1} p\left(x_{1}, \cdots, x_{p}\right)=1
$$

を満たす.$k$ 個 $(k<p)$ の変数を要素にもつ変数集合 $\left\{X_{1}\right.$, $\left.\cdots, X_{k}\right\}$ と, 产の変数集合に $X_{k+1}$ を加えた変数集合 $\left\{X_{1}, \cdots, X_{k}, X_{k+1}\right\}$ に関する同時確率 $p\left(x_{1}, \cdots, x_{k}\right)$, $p\left(x_{1}, \cdots, x_{k}, x_{k+1}\right)$ が , 次の 2 つの確率モデル

$\left\{\begin{array}{l}p\left(x_{1}, \cdots, x_{k}\right)=p\left(x_{1}\right) \cdots p\left(x_{k}\right) \\ p\left(x_{1}, \cdots, x_{k}, x_{k+1}\right) \neq p\left(x_{1}\right) \cdots p\left(x_{k}\right) p\left(x_{k+1}\right)\end{array}\right.$

を満たすとき，変数 $X_{k+1}$ を顕示変数とする．

本研究の目的は, 単純に顕示变数を効率的に選択する のでなく，頑強性をもつ顕示変数を選択することである． 本稿での「頑強性」とは，与えたデータから選択した 変数が, 弚のデータに摂動を与えたデータからも, 同じ ように選択できることをいう．このように頑強性をもつ 变数を選択することにより, (1) を高度に支持する顕示 変数を選択することができる.

本提案手法では, 効率的に頑強性をもつ顕示変数を選 択するためにアプリオリアルゴリズム [Agrawal 94] を応 用する . アプリオリアルゴリズムの詳細を次章で述べる .

\section{2. 相関ルールとアプリオリアルゴリズム}

相関ルール [Agrawal 93](以降，ルールと記す) とは， ある商品とある商品が同時に購買された商品同士を矢印 を使って表すものである.ユーザーは, 閾値として产の 商品同士の最低購買頻度を指定し, 兴の最低頻度を満た す全ての商品のルールを抽出することが目的である . 例 えば商品 $A$ と商品 $B$ のルールを

$A \Rightarrow B$

とあらわす.アソシェーション分析では, この頻度のこ とをサポート (support) とよび, 最低購買頻度を最小サ ポートとよぶ .ルールのサポートだけに注目する場合は， 矢印の方向は本質的な意味を持たず， $B \Rightarrow A$ と等価であ る、本稿は, これ以降，サポートだけを議論する.データ の中の全ての 2 值変数の集合を $V$ として, 商品 $\mathrm{A}$ の購買· 非購買を表す変数を $X(X \in V)$, 商品 $\mathrm{B}$ を $Y(Y \in V)$ とすると, ルール $A \Rightarrow B$ は自然に

$(X=1) \Rightarrow(Y=1)$
と表すことが出来る.ただし, 2 值応答は, 1 を購買, 0 を非購買とする.よって, サポートは, 変数集合 $\{X Y\}$ の $2 \times 2$ の 2 元分割表の同時購買の頻度を表すセルだけ に注目をしていることになる．本稿では， $k$ 個の変数か らなる変数集合を $k$ 次の変数集合といい, 対応する分割 表を $k$ 元分割表という . 同樣の議論により，ルールを多 次元まで拡張することができる . 例えば，(2)に任意の変 数 $Z(Z \in V)$ を要素に加えた 3 次の変数集合 $\{X Y Z\}$ のルールは

$(X=1) \Rightarrow(Y=1)(Z=1)$

と書き, 対応する分割表は, $2 \times 2 \times 2$ の 3 元分割表にな る.

アプリオリアルゴリズムは, ID 付き POS データ等の 顧客の購買履歴データからルールを抽出するアルゴリズ ムであり，データは 2 值データを仮定する .このアルゴリ ズムは, ルールのサポートが逆単調性 (anti-monotone) もつことを利用し，ユーザーが与えた最小サポートを満 たさないルールを生成しないようにしている、特に，最 小サポートを満たす変数集合を頻出変数集合という，例 えば , ルール $(2)$ のサポートを

support $[(X=1) \Rightarrow(Y=1)]$

と表し , ルール (3)のサポートを

$\operatorname{support}[(X=1) \Rightarrow(Y=1)(Z=1)]$

と表すと, サポートの逆単調性とは, $\forall Z \in V$ に対して

$$
\begin{aligned}
& \operatorname{support}[(X=1) \Rightarrow(Y=1)] \geq \\
& \operatorname{support}[(X=1) \Rightarrow(Y=1)(Z=1)]
\end{aligned}
$$

が成り立つ性質である．すなわち，ある任意の変数集合 が頻出変数集合ならば, 兴の部分集合は必す頻出変数集 合になる .上式の不等号が逆の場合で成り立つ性質を単 調性 (monotone) をもつという .

$k$ 次の頻出変数集合の集合を $L_{k}$ と表す .このアルゴリ ズムは, 逆単調性の性質を使いながら $L_{k}$ から $C_{k+1}$ の 生成 $(k \geq 2)$ を効率化したものである.ただし， $C_{k+1}$ は $L_{k+1}$ の候補の集合である.すなわち， $C_{k+1}$ の要素は必 ず頻出変数集合になるとは限らない．アプリオリアルゴ リズムは, 产の頻出変数集合の候補の生成において，必 ず頻出変数集合にならない候補を生成しないことによっ て効率化を図るものである . 兴の詳しい動作を以下に述 ベる.

アプリオリアルゴリズムは , Join-Step と Prune-Step から構成されている.いま, 変数集合の変数の並びは, あ らかじめ決まった任意の順序に従ってソートされている とする . このとき, $k$ 個の変数 $c_{1}, c_{2}, \cdots, c_{k}$ からなる $k$ 次の変数集合 $\left\{c_{1} c_{2} \cdots c_{k}\right\}$ において, 一番右側の変数 $c_{k}$ を最後の変数とよび, $c_{1}$ を最初の変数とよぶことにする. アルゴリズムの動作を以下に示す． 
Join-Step $L_{k}$ の各変数集合に対して，変数集合の変 数の最後の 1 変数だけが違う変数集合同士を結合さ せ新たな变数集合を生成する.

Prune-Step Join-Step で生成した新たな变数集合の 部分集合が， $L_{k}$ にないものを削除する.削除されな かった変数集合を $C_{k+1}$ の要素にする .

$C_{k+1}$ から $L_{k+1}$ の生成は, データに対して実際にサポー 卜を数えることで最小サポートを満たすかどうかを確認し， 満たせば $L_{k+1}$ の要素とする .ここで, この 2 つのステップ の例を示す .いま, $L_{3}$ が $\left\{X_{1} X_{2} X_{3}\right\},\left\{X_{1} X_{2} X_{4}\right\},\left\{X_{1} X_{3}\right.$ $\left.X_{4}\right\},\left\{X_{1} X_{3} X_{5}\right\},\left\{X_{2} X_{3} X_{4}\right\}$ のとき,Join-Step で $\left\{X_{1}\right.$ $\left.X_{2} X_{3}\right\}$ と $\left\{X_{1} X_{2} X_{4}\right\}$ ガ結合し $\left\{X_{1} X_{2} X_{3} X_{4}\right\}$ を, $\left\{X_{1}\right.$ $\left.X_{3} X_{4}\right\}$ と $\left\{X_{1} X_{3} X_{5}\right\}$ が結合して $\left\{X_{1} X_{2} X_{4} X_{5}\right\}$ を生成 する.Prune-Stepでは $\left\{X_{1} X_{2} X_{4} X_{5}\right\}$ の部分集合 $\left\{X_{1} X_{4}\right.$ $\left.X_{5}\right\}$ が $L_{3}$ の要素ではないので, $\left\{X_{1} X_{2} X_{4} X_{5}\right\}$ は削除 される.結局， $C_{4}$ は $\left\{X_{1} X_{2} X_{3} X_{4}\right\}$ だけになる .

Join-Stepの効率性を上の例を使って説明する . $\left\{X_{1} X_{2}\right.$ $\left.X_{3}\right\}$ と $\left\{X_{1} X_{2} X_{4}\right\}$ が結合して $\left\{X_{1} X_{2} X_{3} X_{4}\right\}$ が生成さ れるということは, $\left\{X_{1} X_{2} X_{3} X_{4}\right\}$ の部分集合として，少 なくとも $\left\{X_{1} X_{2} X_{3}\right\}$ と $\left\{X_{1} X_{2} X_{4}\right\}$ が存在することを意 味する. 逆に考えれば，結合する相手がいない变数集合 に , 任意の $L_{3}$ 中の 1 変数を加えて生成した変数集合の 部分集合には, 確実に $L_{3}$ にない変数集合が含まれる.例 えば, $\left\{X_{2} X_{3} X_{4}\right\}$ に $X_{5}$ を加えて $\left\{X_{2} X_{3} X_{4} X_{5}\right\}$ が生成 されるが，光の部分集合 $\left\{X_{2} X_{3} X_{5}\right\}$ は， $L_{3}$ 中に確実に 含まれない .

\section{3. 従来の手法の問題点}

\section{$3 \cdot 12$ 值データにおける分割表の独立性の検定}

顕示变数の効率的な变数選択の問題について,いまま でほとんと議論されていない，乥れは，2 值データを含 めた質的データの分析手法が大規模データをあまり想定 していなかったためである .

(1)より，顕示変数を選択するためには，独立な変数集 合と関連のある (独立ではない) 変数集合を効率よく識別 することが重要になる . 2 值データにおける関連のある変 数集合を抽出する方法を, [Brin 97, Silverstein 98] か提 案した．しかし, 弚の手法は, 变数の頑強性を考慮して いない. [Brin 97, Silverstein 98] は, 関連のある変数を ルールとみなして選択しており，产のルールを correlation rule と呼んでいる.例えば，変数集合 $\left\{X_{1} X_{2} X_{3}\right\}$ に関 連があれば， $\left\{X_{1} X_{2} X_{3}\right\}$ は correlation ruleである。

correlation rule の抽出アルゴリズムは , 全ての関連の ある変数集合を選択するために，独立の判断をピアソン の独立性の検定を用いて判断している．すなわち，帰無 仮説「変数集合が独立である」を棄却すれば関連がある と判断し，採択すれば独立であると判断する。

2 值データでは变数集合の次元に関係なく光の検定統 計量の $\chi^{2}$ 值は, 自由度 1 のカイ二乗分布に従うと [Brin
97, Silverstein 98] は述べており, 兴の場合, 任意の変 数集合 $Z, Y(Z \subset Y)$ の対応するカイ 2 值 $\chi^{2}(Z), \chi^{2}(Y)$ は

$$
\chi^{2}(Z) \leq \chi^{2}(Y)
$$

の単調性の関係が成り立つことを証明した .この単調性 を利用することによって， $\chi^{2}$ 值によって棄却される最小 次元の変数集合さえわかれば, 全ての独立でない变数集 合を網羅したことなり，同時に，全ての独立な変数集合 も網羅できる .

一般に 3 元以上の分割表に関するピアソンの独立性の 検定についてあまり論じられていない，独立な 3 次元以 上の分割表のカイ二乗値の確率分布をシミュレーション を用いて次節で検証する。

\section{$3 \cdot 2$ 多次元分割表のカイ二乗値の分布}

$X_{1}, X_{2}, \cdots, X_{5}$ は互いに独立な 0.5 のベルヌーイ分布 に従う確率変数とし, 各確率変数から 1000 個のサンプル を生成し，弚のサンプルから $\left\{X_{1} X_{2}\right\},\left\{X_{1} X_{2} X_{3}\right\}, \cdots$ ， $\left\{X_{1} X_{2} X_{3} X_{4} X_{5}\right\}$ の $2 \sim 5$ 元分割表のカイ二乗値を求め る. この操作の 10000 回のシュミレーションから得られ たカイ二乗值の正規化されたヒストグラムを図 1 に示す． 各ヒストグラムの実線は, 各々, 自由度 (d.f.) $1,4,11,26$ のカイ二乗分布の密度関数を表す.この結果より，独立 な 2 值データの分割表におけるカイ二乗値は, 常に自由 度 1 のカイ二乗分布に従わず, $k$ 元分割表 ( $k$ ways C.T. と記す)のカイ二乗值は, 自由度 $2^{k}-(k+1)$ のカイ二乗 分布に従うことがわかる．また，同時に単調性も成り立 たず，[Brin 97, Silverstein 98] の手法を谷のまま適用す ると，実際の分布のもとでの有意確率が大きくなり，高 次の分割表ほど棄却されやすくなる .

\section{4. 変数選択アルゴリズム}

\section{$4 \cdot 1$ 独立な変数の逆単調性}

2 次変数集合 $\left\{X_{1} X_{2}\right\}$ が互いに独立とは, 弚の同時確 率 $p\left(x_{1}, x_{2}\right)$ が $p\left(x_{1} . x_{2}\right)=p\left(x_{1}\right) p\left(x_{2}\right)$ のときに成り立つ. 同樣の議論により, 3 次变数集合 $\left\{X_{1} X_{2} X_{3}\right\}$ か互いに独 立であれば, 光の同時確率 $p\left(x_{1}, x_{2}, x_{3}\right)$ は $p\left(x_{1}, x_{2}, x_{3}\right)=$ $p\left(x_{1}\right) p\left(x_{2}\right) p\left(x_{3}\right)$ となる . もし $\left\{X_{1} X_{2} X_{3}\right\}$ の ${ }_{3} C_{2}$ 個の 部分集合が独立でないなら， $\left\{X_{1} X_{2} X_{3}\right\}$ も明らかに独立 ではない、逆に，独立な変数集合を生成するためには，光 の部分集合が独立でなければならない.よって，この変 数集合の独立性には, 逆単調性が成り立つ。

变数集合が,独立か関連があるかを判断するために, 何 らかの指標 (判断基準) が必要である.一般的には前述し たピアソンの独立性の検定や確率モデルの AIC の比較が ある.しかし, 何れの指標にも逆単調性の性質がないた め，例えば $\left\{X_{1} X_{2} X_{3}\right\}$ が独立と判断されたからといっ て，弚の部分集合 $\left\{X_{1} X_{2}\right\}$ か独立と判断される確実な保 
Chi^2 Value (2way C.T.)

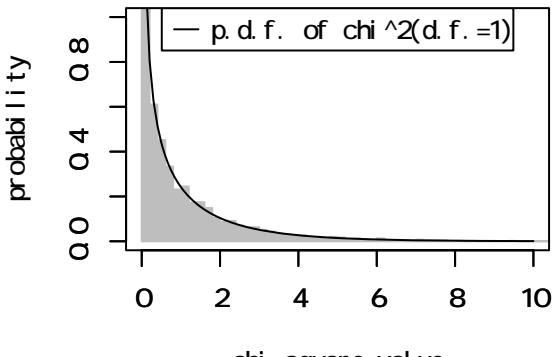

chi square val ue

Chi^2 Value (4way C.T.)

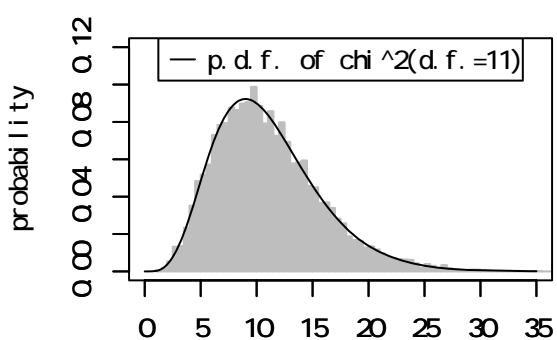

chi square val ue

図 12 值データにおける多次元分割表のカイ二乗値の分布
Chi^2 Value(3way C.T.)

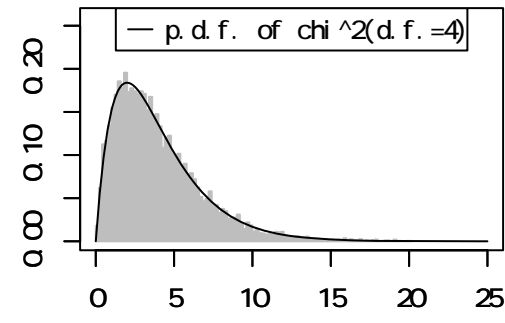

chi square val ue

Chi^2 Value (5way C.T.)

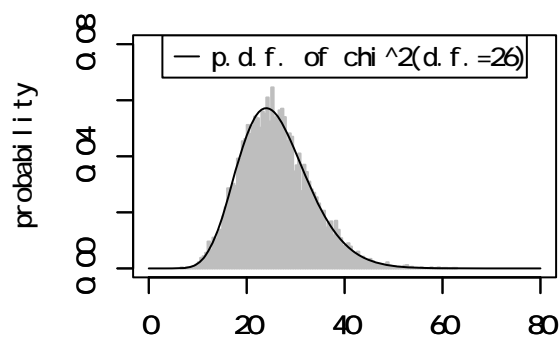

chi square val ue
証はない. 本研究の目的は,ある指標のもとで独立と判断 される全ての変数集合を選択することではなく，頑強性 をもつ顕示変数を選択することである . 兴のため , (1)の $p\left(x_{1}, \cdots, x_{k}\right)=p\left(x_{1}\right) \cdots p\left(x_{k}\right)$ に注目し,$p\left(x_{1}\right) \cdots p\left(x_{k}\right)$ に関して頑強性をもつ変数集合を選択することよって，光 の目的を達成する方法をとる. 本手法では，独立性を判 断する基準として分割表の確率モデルの AIC を用いる . 弚の AIC については, 次節で述べる。

\section{$4 \cdot 2$ 分割表の確率モデルの $\mathrm{AIC}$}

本研究では, 分割表における確率モデルの AIC によっ て顕示変数を判断する. 产のモデルの導出を以下で行う . データには, $p$ 個の変数 $X_{i}(i=1, \cdots, p)$ があり, 值 0,1 をとる.$k$ 個の変数からなる任意の変数集合 $c=\left\{X_{1}, \cdots\right.$, $\left.X_{k}\right\} \quad(k \leq p)$ が值 $x_{1}, \cdots, x_{k}$ をとる確率を $p\left(x_{1}, \cdots, x_{k}\right)$ とし, 対応する観測度数を $n\left(x_{1}, \cdots, x_{k}\right)$ とすると，

$$
\begin{aligned}
& \sum_{x_{1}=0}^{1} \cdots \sum_{x_{k}=0}^{1} p\left(x_{1}, \cdots, x_{k}\right)=1 \\
& \sum_{x_{1}=0}^{1} \cdots \sum_{x_{k}=0}^{1} n\left(x_{1}, \cdots, x_{k}\right)=n
\end{aligned}
$$

である．ただし， $n$ はサンプルサイズである ．母集団が 十分大きいとすると, 確率 $p\left(x_{1}, \cdots, x_{k}\right)$ の下での観測度
数の集合 $n\left(x_{1}, \cdots, x_{k}\right)$ が得られる確率は, 多項分布

$$
\begin{aligned}
M & \left(n\left(x_{1}, \cdots, x_{k}\right) \mid p\left(x_{1}, \cdots, x_{k}\right)\right) \\
= & \frac{n !}{\prod_{x_{1}=0}^{1} \cdots \prod_{x_{k}=0}^{1} n\left(x_{1}, \cdots, x_{k}\right) !} \\
& \times \prod_{x_{1}=0}^{1} \cdots \prod_{x_{k}=0}^{1} p\left(x_{1}, \cdots, x_{k}\right)^{n\left(x_{1}, \cdots, x_{k}\right)}
\end{aligned}
$$

で与えられる.いま, $n\left(x_{1}, \cdots, x_{k}\right)$ が与えられたもとでの $p\left(x_{1}, \cdots, x_{k}\right)$ の対数尤度関数 $l\left(p\left(x_{1}, \cdots, x_{k}\right) \mid n\left(x_{1}, \cdots, x_{k}\right)\right)$ は, $p\left(x_{1}, \cdots, x_{k}\right)$ に無関係な定数項を無視すれば

$$
\begin{aligned}
& l\left(p\left(x_{1}, \cdots, x_{k}\right) \mid n\left(x_{1}, \cdots, x_{k}\right)\right) \\
& =\sum_{x_{1}=0}^{1} \cdots \sum_{x_{k}=0}^{1} n\left(x_{1}, \cdots, x_{k}\right) \log p\left(x_{1}, \cdots, x_{k}\right)(6)
\end{aligned}
$$

で与えられる，一般に成り立つ関係

$p\left(x_{1}, x_{2}, \cdots, x_{k}\right)=p\left(x_{1}, x_{2}, \cdots, x_{k-1} \mid x_{k}\right) p\left(x_{k}\right)$

について，次の 3 つのモデルを考える .1) 独立を仮定す るモデルModel (Ind) を，

$$
\text { Model(Ind): } \begin{aligned}
& p\left(x_{1}, x_{2}, \cdots, x_{k-1} \mid x_{k}\right) p\left(x_{k}\right) \\
& =p\left(x_{1}\right) p\left(x_{2}\right) \cdots p\left(x_{k-1}\right) p\left(x_{k}\right)
\end{aligned}
$$

とする .2) $X_{1}, \cdots, X_{k}$ の関連を仮定するモデルModel (Dep) を

$$
\begin{aligned}
\operatorname{Model}(\mathrm{Dep}): & p\left(x_{1}, x_{2}, \cdots, x_{k-1} \mid x_{k}\right) p\left(x_{k}\right) \\
& =p\left(x_{1}, x_{2}, \cdots, x_{k}\right)
\end{aligned}
$$


とする . 3) $X_{k}$ の条件のもとで $X_{1}, \cdots, X_{k-1}$ の独立を 仮定する条件付独立モデルModel（Cin）を

$$
\begin{gathered}
\text { Model (Cin): } \quad p\left(x_{1}, x_{2}, \cdots, x_{k-1} \mid x_{k}\right) p\left(x_{k}\right) \\
\quad=p\left(x_{1} \mid x_{k}\right) p\left(x_{2} \mid x_{k}\right) \cdots p\left(x_{k-1} \mid x_{k}\right) p\left(x_{k}\right)
\end{gathered}
$$

とする . この 3 つのモデルの AIC を以下で導出する .

\section{$\S 1$ Model(Ind) の AIC}

Model (Ind) は, 以下の制約条件

$\sum_{x_{1}=0}^{1} p\left(x_{1}\right)=\cdots=\sum_{x_{k}=0}^{1} p\left(x_{k}\right)=1$

をもつ.ただし,$p\left(x_{1}\right)=\sum_{x_{2}=0}^{1} \cdots \sum_{x_{k}=0}^{1} p\left(x_{1}, \cdots, x_{k}\right)$, $\cdots, p\left(x_{k}\right)=\sum_{x_{1}=0}^{1} \cdots \sum_{x_{k-1}=0}^{1} p\left(x_{1}, \cdots, x_{k}\right)$. よって , Model (Ind) の自由パラメータの個数は, $2 k$ 個である .こ の個数と Model (Ind) における (6) の最尤推定量 $\tilde{p}\left(x_{i}\right)=$ $n\left(x_{i}\right) / n(i=1, \cdots, k)$ を考慮すると，Model(Ind) の AICAIC (Model (Ind)) は

$$
\begin{aligned}
& \operatorname{AIC}(\text { Model }(\text { Ind }))= \\
& (-2) \sum_{x_{1}=0}^{1} \cdots \sum_{x_{k}=0}^{1} n\left(x_{1}, x_{2}, \cdots, x_{k}\right) \times \\
& \quad \log \frac{n\left(x_{1}\right) n\left(x_{2}\right) \cdots n\left(x_{k}\right)}{n^{k}}+2(k)
\end{aligned}
$$

となる .

$\S 2$ Model (Dep) の AIC

Model (Dep) は, 以下の制約条件

$\sum_{x_{1}=0}^{1} \cdots \sum_{x_{k}=0}^{1} p\left(x_{1}, x_{2}, \cdots, x_{k}\right)=1$

をもつ.よって,Model (Dep) は $2^{k}-1$ 個の自由パラメー タをもつ. この個数と Model (Dep) のもとでの (6) の最 尤推定量 $\tilde{p}\left(x_{1}, x_{2}, \cdots, x_{k}\right)=n\left(x_{1}, x_{2}, \cdots, x_{k}\right) / n$ を考慮 すると, 光の AICAIC (Model (Dep)) は

$$
\begin{aligned}
& \operatorname{AIC}(\operatorname{Model}(\operatorname{Dep}))= \\
& (-2) \sum_{x_{1}=0}^{1} \cdots \sum_{x_{k}=0}^{1} n\left(x_{1}, x_{2}, \cdots, x_{k}\right) \times \\
& \log \frac{n\left(x_{1}, x_{2}, \cdots, x_{k}\right)}{n}+2\left(2^{k}-1\right)
\end{aligned}
$$

となる .

$\S 3$ Model(Cin) の AIC

Model (Cin) は, 以下の制約条件

$$
\left\{\begin{array}{l}
\sum_{x_{1}=0}^{1} p\left(x_{1} \mid x_{k}\right)=\cdots=\sum_{x_{k-1}=0}^{1} p\left(x_{k-1} \mid x_{k}\right)=1 \\
\left(x_{k}=0,1\right) \\
\sum_{x_{k}=0}^{1} p\left(x_{k}\right)=1
\end{array}\right.
$$

をもつ.よって, Model(Cin) は $2 k-1$ の自由パラメー タをもつ. この個数と Model (Cin) のもとでの (6) の最 尤推定量

$$
\begin{aligned}
\tilde{p}\left(x_{i} \mid x_{k}\right) & =\frac{n\left(x_{i}, x_{k}\right)}{n\left(x_{k}\right)} \quad i=1, \cdots, k-1 \\
\tilde{p}\left(x_{k}\right) & =\frac{n\left(x_{k}\right)}{n}
\end{aligned}
$$

を考慮すると，弚のAICAIC (Model(Cin)) は

$$
\begin{array}{r}
(-2) \sum_{x_{k}=0}^{1}\left(\sum_{x_{1}=0}^{1} n\left(x_{2}, x_{k}\right) \log \frac{n\left(x_{2}, x_{k}\right)}{n\left(x_{k}\right)}+\cdots\right. \\
+\sum_{x_{k-1}=0}^{1} n\left(x_{k-1}, x_{k}\right) \log \frac{n\left(x_{k-1}, x_{k}\right)}{n\left(x_{k}\right)}+n\left(x_{k}\right) \times \\
\left.\log \frac{n\left(x_{k}\right)}{n}\right)+2(2 k-1)
\end{array}
$$

となる

\section{$4 \cdot 3$ 独立な変数集合の生成}

本研究では, 頑強性をもつ独立な変数集合を選択する方 法として, 選択する独立な変数集合が, AIC による独立性 の判断に関して逆単調性を満たす変数集合を選択する.乥 れは, 例えば, 選択した変数集合 $\left\{X_{1} X_{2} X_{3}\right\}$ は, 弚の全 ての部分集合 $\left\{X_{1} X_{2}\right\},\left\{X_{1} X_{3}\right\},\left\{X_{2} X_{3}\right\},\left\{X_{1} X_{2} X_{3}\right\}$ が, 独立であると判断されている変数集合になる. 逆に，

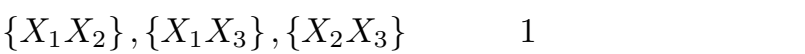
と判断されれば， $\left\{X_{1} X_{2} X_{3}\right\}$ を選択しない．このような 性質を満たす変数集合が, 独立に関して頑強性をもつと いうことを数值実験によって確認する．

いま, $X_{1}, \cdots, X_{k} \quad k=3, \cdots, 6$ は, 互いに独立な 0.5 のベルヌーイ分布に従う確率変数とし, データ $D$ は $k$ 個 の確率変数から生成した 1000 個のサンプルによって構 成する. $\left\{X_{1} X_{2}, \cdots, X_{k}\right\}$ の独立な部分集合の個数のパ ターンの頻度と，弚のときの $\left\{X_{1} X_{2}, \cdots, X_{k}\right\}$ の独立の 頑強性は, $D$ と同じサンプルサイズで 1000 回のブート ストラップ複製で評価する . パターンとは, 例えば $k=3$ とすれば， 2 次の独立な部分集合が 2 個，3 次の独立な 部分集合が 1 個のとき， $\{2,1\}$ が 1 つのパターンになる . ブートストラップによる評価とは，例えば $k=3$ のとき， 変数集合 $c=\left\{X_{1} X_{2} X_{3}\right\}$ の独立の頑強性を，1000 回の ブートストラップ複製によって AIC (Model (Ind) , c) < AIC (Model (Dep), c) の関係を満たす確率を求めること である、ただし，AIC (Model (Dep),c) は, 変数集合 $c$ のModel(Dep) の AIC を表す . 以上の操作の 5000 回の シミュレーションによって, パターンの頻度とブートス トラップ確率の平均値を算出する . また，独立の判定に つい, [Brin 97, Silverstein 98] の自由度 1 のカイ 2 乗 の独立性の検定方法 (有意確率 5\%) との比較を行った。 弚の実験結果を表 2 に示す。 


\begin{tabular}{|c|c|c|c|c|c|c|c|c|c|c|c|c|c|}
\hline & & & $s_{3}^{(2)}$ & $s_{3}^{(3)}$ & $\begin{array}{c}k=3 \\
\text { freq }\end{array}$ & b.s. prob & $s_{4}^{(2)}$ & $s_{4}^{(3)}$ & $\begin{array}{r}k \\
s_{4}^{(4)}\end{array}$ & $\begin{array}{l}4 \\
\text { freq }\end{array}$ & \multicolumn{2}{|c|}{ b.s. prob } & \\
\hline & & \multirow{3}{*}{$\mathrm{AIC}$} & 3 & 1 & 2941 & 70.8 & 6 & 4 & 1 & 1778 & \multicolumn{2}{|c|}{70.4} & \\
\hline & & & 2 & 1 & 1437 & 50.3 & 5 & 4 & 1 & 1519 & \multicolumn{2}{|c|}{59.9} & \\
\hline & & & 1 & 1 & 155 & 39.9 & 4 & 4 & 1 & 404 & \multicolumn{2}{|c|}{51.9} & \\
\hline & & \multirow{3}{*}{$\chi^{2}(1)$} & 3 & 1 & 2836 & 34.9 & 6 & 4 & 1 & 137 & \multicolumn{2}{|c|}{0.8} & \\
\hline & & & 3 & 0 & 1458 & 13.8 & 6 & 4 & 0 & 949 & \multicolumn{2}{|c|}{0.2} & \\
\hline & & & 1 & 0 & 36 & 1.5 & 6 & 3 & 0 & 1082 & \multicolumn{2}{|c|}{0.1} & \\
\hline & \multicolumn{6}{|c|}{$k=5$} & \multicolumn{7}{|c|}{$k=6$} \\
\hline & $s_{5}^{(2)}$ & $s_{5}^{(3)}$ & $s_{5}^{(4)}$ & $s_{5}^{(5)}$ & freq & b.s prob. & $s_{6}^{(2)}$ & $s_{6}^{(3)}$ & $s_{6}^{(4)}$ & $s_{6}^{(5)}$ & $s_{6}^{(6)}$ & freq & b.s. prob. \\
\hline \multirow{3}{*}{ AIC } & 10 & 10 & 5 & 1 & 779 & 70.0 & 15 & 20 & 15 & 6 & 1 & 300 & 69.1 \\
\hline & 9 & 10 & 5 & 1 & 1092 & 63.8 & 14 & 20 & 15 & 6 & 1 & 595 & 63.4 \\
\hline & 8 & 10 & 5 & 1 & 574 & 58.8 & 13 & 20 & 15 & 6 & 1 & 462 & 61.8 \\
\hline \multirow{3}{*}{$\chi^{2}(1)$} & 10 & 7 & 0 & 0 & 482 & 0.0 & 14 & 11 & 0 & 0 & 0 & 209 & 0.0 \\
\hline & 10 & 6 & 0 & 0 & 454 & 0.0 & 14 & 10 & 0 & 0 & 0 & 191 & 0.0 \\
\hline & 10 & 8 & 0 & 0 & 435 & 0.0 & 15 & 13 & 0 & 0 & 0 & 190 & 0.0 \\
\hline
\end{tabular}

表 2 は, ブートストラップ確率 (b.s. prob と記す) で 降順にソートしたものから上位 3 位のみを表示してい る.ただし , ブートストラップ確率がタイの場合は , パ ターンの出現頻度 (freq と記す) で降順にソートしてい る. $s_{k}^{(m)} m=2, \cdots, k$ は, $k$ 次の変数集合における $m$ 次 の部分集合の中で, AIC によって独立を判断された個数 を表す.よって, $s_{k}^{(k)}$ は, $k$ 次の変数集合光のものが独 立のときに 1 になる .

表 2 の各 $k$ の AIC の結果より，全ての部分集合か独立 のとき, すなわち ${ }_{k} C_{i}=s_{k}^{(i)} i=2, \cdots, k$ のときに, 光 の変数集合のブートストラップ確率が最も高いことがわ かる.よって, AICの判断に関して逆単調性を満たす変 数集合が, より独立に関して頑強性をもつといえる. 各 $k$ の $\chi^{2}(1)$ の結果より, 前述したとおり, 高次の変数集 合に対して，帰無仮説を棄却するために独立と判断され ないことがわかる .

\section{$4 \cdot 4$ 变数選択アルゴリズム}

前述した AIC を用いた顕示変数の選択・識別方法を述 べる. (1)の顕示変数の定義に対応して, 以下の関係

$$
\left\{\begin{array}{c}
\operatorname{AIC}(\operatorname{Model}(\text { Ind }), c)<\operatorname{AIC}(\operatorname{Model}(\operatorname{Dep}), c) \\
\min _{R \in\{\text { Ind,Dep }, \text { Cin }\}} \operatorname{AIC}\left(\operatorname{Model}(R), c \cup X_{k+1}\right)= \\
\operatorname{AIC}\left(\operatorname{Model}(\text { Dep }), c \cup X_{k+1}\right)
\end{array}\right.
$$

成り立つとき， $X_{k+1}$ を顕示変数として選択する．ただ し, 変数集合 $c=\left\{X_{1}, \cdots, X_{k}\right\}$ である. 提案するアルゴ リズムを図 2 に示す .このアルゴリズムの補足説明をア ルゴリズムの行番号ごとに述べる .

Line 2) データ $D$ は, $p$ 個の 2 值変数 $X_{1}, X_{2}, \cdots, X_{p}$ をもつ.
Line 4) 2 次の変数集合 $c$ が AIC (Model (Ind), $c)<$ AIC (Model (Dep),c) のとき , $I_{2}$ の要素にする .

Line 6) 7) Join-Step は, $I_{k}$ の要素である独立な変 数集合から, $k+1$ 次の独立になる候補の変数集合 を生成する.Prune-Step では, 弚の变数集合の部分 集合が， $I_{k}$ にないもの削除する.

Line 15〜16) AIC(Model (Cin), d) は, $v$ を条件とす るModel(Cin)のAICである.Model (Dep) を支持 する変数集合 $d$ をみつけるためにModel (Ind) との 関係だけでなく，Model(Cin) も考慮する理由は， $d$ がModel (Dep) 以外のモデルを支持する場合，乥れ は顕示変数の定義を満たさないことになるため.比較 するモデルが多いほどModel (Dep) の支持の信頼性 か増すことになる．しかし，考えられるModel (Dep) 以外の全てのモデルの個数は膨大なため, 弚れら全 てを比較することは困難である.変数集合 $i$ は, 独 立に関して頑強性をもつ変数集合であるから, $v$ が 条件のもとで $i$ が独立になる条件付独立の状態にな る可能性が高い.よって,Model（Cin）を比較の対 象として考慮している．弚の有効性を次章の数值実 験で示す。

\section{5. 数 值 実 験}

2 值の人工データを用いて，本提案手法の有効性を確 認する.実験方法と光の結果を以下に示す .

\section{$5 \cdot 1$ 実 験 方 法}

$X_{1}, X_{2}, X_{3}$ は, 互いに独立で 0.5 のベルヌーイ分布に 従う変数とし， $X_{1}, X_{2}, X_{3}$ に関する顕示変数 $X_{4}$ を作成 するために, 弚の 3 変数の表 3 に示す実現値に応じて $95 \%$ 


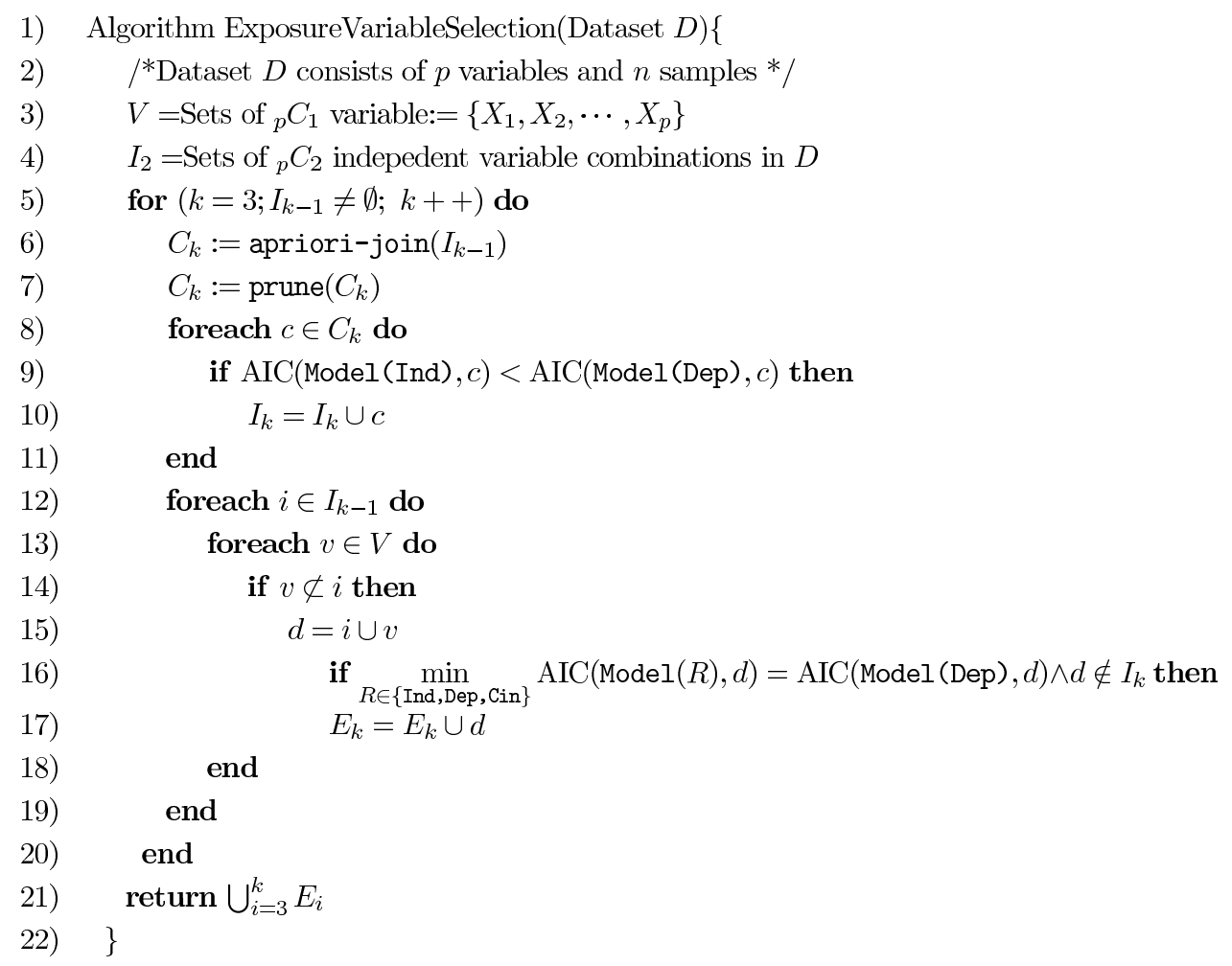

図 2 顕示変数選択アルゴリズム

表 3 顕示変数 $X_{4}$ の生成パターン

\begin{tabular}{ccc|c}
$X_{1}$ & $X_{2}$ & $X_{3}$ & $X_{4}$ \\
\hline 0 & 0 & 0 & 1 \\
0 & 0 & 1 & 0 \\
0 & 1 & 0 & 0 \\
0 & 1 & 1 & 1 \\
1 & 0 & 0 & 0 \\
1 & 0 & 1 & 0 \\
1 & 1 & 0 & 1 \\
1 & 1 & 1 & 0
\end{tabular}

の確率で $X_{4}$ を生成する $\left(5 \%\right.$ の確率で， $X_{4}$ に 0,1 をラン ダムに与える) $. X_{5}, \cdots, X_{8}$ と $X_{9}, \cdots, X_{12}$ は独立で同 一な表 4 に示す確率をもつ同時分布に従う変数とする.残 る 4 変数 $X_{12}, \cdots, X_{15}$ は, 互いに独立で 0.5 のベルヌー イ分布に従う変数とする. $X_{1}, \cdots, X_{15}$ から 1000 個のサ ンプルを生成したものをデータセット $D$ とする.顕示変 数 $X_{4}$ の選択の有無ごとに $\left\{X_{1} X_{2} X_{4}\right\},\left\{X_{1} X_{2} X_{3} X_{4}\right\}$ の頑強性を評価するために, $D$ と同じサンプルサイズの 1000 回のブートストラップ複写によって , $\left\{X_{1} X_{2} X_{3}\right\}$ の図 3 の Line 9), $\left\{X_{1} X_{2} X_{3} X_{4}\right\}$ の Line 16) の関係を 支持するブートストラップ確率を求める . 以上の操作の 1000 回のシミュレーションによって得られる顕示変数の 選択頻度とブートストラップ確率の平均值を算出する．

\section{$5 \cdot 2$ 実 験 結 果}

実験結果を表 5 に示す. 表 5 の $S, \neg S$ は，弚れ光れ 本提案手法によって $\left\{X_{1} X_{2} X_{3} X_{4}\right\}$ が選択された状態，

\begin{tabular}{cccc|c} 
表 4 & \multicolumn{2}{l}{ 同時分布の設定 } \\
$X_{5,9}$ & $X_{6,10}$ & $X_{7,11}$ & $X_{8,12}$ & $p$ \\
\hline 0 & 0 & 0 & 0 & 0.3 \\
0 & 0 & 0 & 1 & $\frac{0.4}{14}$ \\
0 & 0 & 1 & 0 & $\frac{0.4}{14}$ \\
0 & 0 & 1 & 1 & $\frac{0.4}{14}$ \\
0 & 1 & 0 & 0 & $\frac{0.4}{14}$ \\
0 & 1 & 0 & 1 & $\frac{0.4}{14}$ \\
0 & 1 & 1 & 0 & $\frac{0.4}{14}$ \\
0 & 1 & 1 & 1 & $\frac{0.4}{14}$ \\
1 & 0 & 0 & 0 & $\frac{0.4}{14}$ \\
1 & 0 & 0 & 1 & $\frac{0.4}{14}$ \\
1 & 0 & 1 & 0 & $\frac{0.4}{14}$ \\
1 & 0 & 1 & 1 & $\frac{0.4}{14}$ \\
1 & 1 & 0 & 0 & $\frac{0.4}{14}$ \\
1 & 1 & 0 & 1 & $\frac{0.4}{14}$ \\
1 & 1 & 1 & 0 & $\frac{0.4}{14}$ \\
1 & 1 & 1 & 1 & 0.3
\end{tabular}

選択されなかった状態を表す. $S$ の頻度 (Frequncy と 記す) は，595 回 (59.5\%) と高い值ではない.これは人 エデータが, 頑強性のある顕示変数ばかりを生成するも のではく，頑強性をもたない顕示変数も生成しているた めである．弚のため，頻度谷のものを注目するのはでは

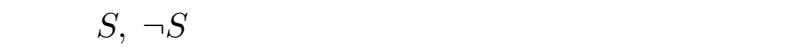
率に注目する必要がある . $S, \neg S$ の $\left\{X_{1} X_{2} X_{3} X_{4}\right\}$ の

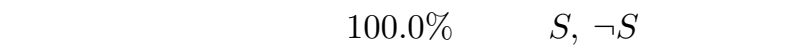
$\left\{X_{1} X_{2} X_{3} X_{4}\right\}$ の関連に関する頑強性をもつことがわか 
表 $5\left\{X_{1} X_{2} X_{3}\right\},\left\{X_{1} X_{2} X_{3} X_{4}\right\}$ の選択結果

\begin{tabular}{c|ccc} 
& & \multicolumn{3}{c}{ Bootstrap Probability (\%) } \\
\cline { 2 - 4 } & Frequency & $\left\{X_{1} X_{2} X_{3}\right\}$ & $\left\{X_{1} X_{2} X_{3} X_{4}\right\}$ \\
\hline$S$ & 595 & 70.9 & 100.0 \\
$\neg S$ & 405 & 43.7 & 100.0
\end{tabular}

る.よって, 頑強性のある顕示変数を選択するには, 独立 に関して頑強性をもつ変数集合が選択できるかどうかで 決まる . $\left\{X_{1} X_{2} X_{3}\right\}$ の $S$ のブートストラップ確率 $70.9 \%$ は, $\neg S$ のブートストラップ確率 $43.7 \%$ に比べて高い值 をもつ.これを統計的検定を行って確認する . S のブート ストラップ確率の母平均 $\mu_{S}$ と $\neg S$ のブートストラップ確 率の母平均 $\mu_{\neg S}$ に関して, 帰無仮説 $H_{0}: \mu_{S}=\mu_{\neg S}$, 対 立仮説 $H_{1}: \mu_{S}>\mu_{\neg S}$ のウェルチの検定を行う(有意確 率 $5 \%$ の等分散性の検定結果より等分散性が成り立たな かった）. 产の検定統計量 $t$ は $t=-\frac{0.709-0.437}{\sqrt{\frac{0.015}{595}+\frac{0.023}{405}}}=30.0$ となり, $\mathrm{t}$ 值の $5 \%$ 点 $t_{0.05}(743)=1.64$ より帰無仮説は 棄却される.以上の結果から提案手法は，独立に関して頑 強性をもつ変数集合を選択することができるため, 頑強 性をもつ顕示変数を選択することができることがわかっ た.

次に, 図 2 の Line 16) の Model (Cin) の有効性を示

\begin{tabular}{c|cc} 
表 6 & \multicolumn{3}{c}{ Model(Cin) の有効性 } \\
& $\left(\bigcup_{i=3}^{k} E_{i}\right)$ & $S$-Frequency \\
\hline Ind, Dep & 2717.4 & 595 \\
Ind, Dep, Cin & 177.3 & 595
\end{tabular}

す実験結果を表 6 に示す．表 6 は, Line 16) で，2つの モデルの AIC の関係

$\mathrm{AIC}(\operatorname{Model}(\operatorname{Dep}), d)<\mathrm{AIC}(\operatorname{Model}($ Ind $), d)$

で比較した場合と本選択アルゴリズムのように，3つの モデルの AIC の関係で比較した場合の $\left(\bigcup_{i=3}^{k} E_{i}\right)$ の平 均個数と $\left\{X_{1} X_{2} X_{3} X_{4}\right\}$ の選択頻度 $(S$-Frequency と記 す) を示す . 選択頻度は同数で, $\left(\bigcup_{i=3}^{k} E_{i}\right)$ の平均個数は， 3 つのモデルを使った場合の方が少ないという結果から， $\operatorname{Model}(C i d)$ の導入が, 不要な変数集合を選択しないよ うに有効に機能していることがわかる．

最後に, 変数の個数が 15 個なので, 考えられる全ての 変数集合の個数は約 $2^{15}=32768$ 個である. 本手法では， 考慮した変数集合 $d$ の平均個数は 4758.4 個 (14.5\%) で あり,より少ない変数集合の組合せを探索するだけで顕 示変数を選択できる。

\section{6. ま と め}

本稿では, 効率的な頑強性をもつ顕示変数の選択手法 を提案した . 数值実験の結果から，独立モデルの AIC に 基づく逆単調性を満たす変数集合を選択することにより，
頑強性をもつ顕示変数を効率的に選択することができた . この性質は，例えば，条件付独立をより満たすような変 数を選択する場合にも応用することが可能であると考え られる。

謝辞

本論文を作成するにあたり，大変貴重なコメントを頂 いた査読者殿に感謝致します。

\section{$\diamond$ 参 考 文 献 $\diamond$}

[Agrawal 93] Agrawal, R., Imielinski, T. and Swami, A. (1993). Mining Association rules between sets of items in large databases. The Proceedings of the ACM SIGMOD Conference on Management of Data, 207-216.

[Agrawal 94] Agrawal, R., Imielsinki, T. and Swami, A. (1994). Fast Algorithm for mining association rules. The Proceedings of International Conference on Very Large Data Bases, 487-499.

[Brin 97] Brin, S., Motwani, R. and Silverstein, C. (1997). Beyond market Baskets; Generalizing Association Rules to Correlations. The Proceedings of the ACM SIGMOD '97, 265-276.

[松田 88] 松田 紀之. (1988). 質的情報の多変量解析. 朝倉書店 .

[Sakamoto, 91] Sakamoto, Y. (1991). Categorical Data Analysis. Kluwer Avademic Publishers.

[Silverstein 98] Silverstein, C., Brin, S. \& Motowani. (1998). Beyond Market Baskets; Generalizing Association Rules to Dependence Rules. Data Mining and Knowledge Discovery. 2-1, 39-68.

〔担当委員: 下平 英寿〕

2006 年 8 月 15 日 受理

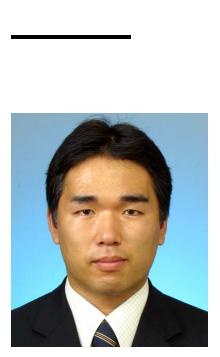

者 紹介

大野学

2000 年東海大学海洋学部船舶工学科卒業. 2003 年立教大 学大学院社会学研究科応用社会学専攻修了. 現在, 岡山大 学大学院自然科学研究科博士後期課程在籍. 専攻は計算機 統計学. 2 值データの分析方法やマーケティングデータ等 の分析方法に興味がある.日本計算機統計学会, 日本マー ケティングサイエンス学会, 日本データベース学会, 日本 船船海洋工学会各会員

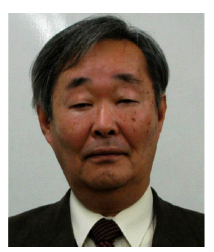

垂水 共之

1970 年九州大学理学部数学科卒業. 1972 年九州大学大 学院理学研究科修士課程修了. 1973 年広島大学助手. 岡 山大学講師, 助教授を経て, 現在, 岡山大学アドミッショ ンセンター教授 (環境学研究科併任). 工学博士 . 統計ソフ トウェア, 空間統計学に興味がある。専攻は計算機統計学。 日本計算機統計学会, 日本統計学会, 応用統計学会, 日本 行動計量学会各会員. 